\title{
Penggunaan Lembar Kerja Siswa Berbasis Kontekstual dan Media Power Poin untuk Meningkatkan Kemampuan Berpikir Kritis dan Motivasi Belajar Siswa di Sekolah Dasar Negeri 2 Tente
}

\author{
Mariamah $^{1}$, Nurbaya $^{2}$, Syahraini $^{3}$ \\ ${ }^{1}$ STKIP Taman Siswa Bima \\ ${ }^{2,3}$ SDN 2 Tente \\ ${ }^{1}$ mariamahmariamah85@yahoo.co.id
}

\begin{abstract}
ABSTRAK
Tujuan penelitian ini adalah untuk mendeskripsikan Penggunaan lembar kerja siswa berbasis kontekstual dan media power poin dalam meningkatkan kemampuan berpikir kritis dan motivasi belajar siswa kelas IV di SD Negeri 2 Tente Tahun pelajaran 2018/2019. Jenis penelitian ini adalah penelitian tindakan kelas dengan rancangan penelitian yang terdiri dari perencanaan, pelaksanaan, observasi dan refleksi. Subyek penelitian adalah siswa kelas IV di SDN 2 Tente. Instrumen yang digunakan ada tiga yaitu instrumen tes untuk mengukur kemampuan berpikir kritis siswa dan lembar angket untuk mengukur motivasi belajar siswa dan lembar observasi aktivitas siswa dan guru. Berdasarkan data hasil penelitian yang dilaksanakan 2 siklus dengan total enam kali pertemuan pada materi pecahan senilai bahwa dengan menggunakan media power poin dan lembar kerja siswa berbasis kontekstual dapat meningkatkan kemampuan berpikir kritis siswa serta meningkatkan motivasi belajar. Hal ini terlihat dari data siklus 1 yang hanya mencapai 61\% ketuntasan secara klasikan untuk aspek kemampuan kemampuan berpikir kritis dan aspek motivasi belajar hanya rata-rata kategori sedang. Kemudian hasil penelitian di siklus II meningkat secara signifikan menjadi 91\% aspek berpikir kritis, untuk aspek motivasi belajar menjadi kategori tinggi.
\end{abstract}

Kata kunci: LKS, power poin, kontekstuan, berpikir kritis, motivasi belajar

\section{PENDAHULUAN}

Matematika merupakan ilmu yang sangat penting dan dibutuhkan dalam menyelesaikan masalah dalam kehidupan sehari-hari, sehingga pelajaran matematika diberikan mulai tingkat sekolah dasar sampai diperguruan tinggi. Ironisnya, masih banyak ditemukan siswa yang tidak menyukai pelajaran matematika, menganggap pelajaran matematika sebagai pelajaran yang sulit dan membosankan. Hal inilah yang perlu diatasi oleh berbagai pihak terutama guru sebagai pengajar dan pihak sekolah serta orang tua. Harapannya agar tujuan pembelajaran matematika tercapai dan dapat dipergunakan dalam kehidupan sehari-hari. Permasalahan utama yang dihadapi oleh guru dalam mengajar matematika di SD Negeri 2 Tente antara lain: 1) siswa belum semuanya aktif dalam mengikuti kegiatan belajar mengajar, 2) masih ada siswa yang belum paham terhadap materi yang disampaikan khusus materi pecahan,
3) kurangnya media pembelajaran yang digunakan dalam mengajarkan materi pecahan yang bersifat kontekstual, 4) kemampuan berpikir kritis siwa masih rendah dilihat dari kemampuan mengidentifikasi nilai dari pecahan, menulis bahasa matematika kurang jelas.

Untuk mengatasi berbagai masalah di atas, perlu dilakukan berbagai usahan kreatif dari guru, salah satu yang lakukan oleh adalah merancang media yang dapat mempermudah siswa untuk menguasai materi yang akan digunakan. Dalam penelitian ini ada dua media yang digunakan yaitu LKS dan power poin berbasis kontekstual. LKS dirancang dengan menampilkan benda-benda kongkrit yang sering dilihat oleh siswa dalam kehidupan sehari, sehingga mempermudah siswa memahami konsep pecahan, begitupun dengan power poin yang dibuat, siswa secara langsung dapat melihat benda-benda yang bisa menjelaskan apa itu pecahan. Menurut Johnson bahwa CTL is an 
educational process that aims to help students see meaning in the academic material they are studying by connecting academic subjects with the context of their daily lives, that is, with context of their personal, social, and cultural circumstance" (Johnson, Elaine B. 2014) dari definisi tersebut dapat diartikan bahwa, CTL adalah sebuah proses pendidikan yang bertujuan untuk membantu siswa melihat makna dalam materi akademik yang mereka pelajari dengan menghubungkan mata pelajaran akademik dengan konteks kehidupan sehari-hari mereka, yaitu, dengan konteks keadaan pribadi, sosial dan budaya mereka. Pembelajaran kontekstual dapat direalisasikan dengan mengembangkan bahan ajar bentuk Lembar Kerja Siswa. LKS adalah panduan siswa yang digunakan untuk melakukan kegiatan penyidikan atau pemecahan masalah. LKS dapat berupa panduan untuk latihan pengembangan aspek kognitif maupun panduan untuk pengembangan semua aspek pembelajaran dalam bentuk panduan eksperimen dan demonstrasi Materi pembelajaran berbasis kontekstual yang dituangkan dalam bahan ajar diharapkan dapat membantu siswa untuk bernalar secara saintifik (Komalasari, Kokom., 2012). Pembelajaran kontekstual adalah ajaran dan konsep belajar yang membantu guru untuk mengkorelasikan bahan mengajar dan situasi nyata siswa dan mendorong siswa untuk membuat hubungan antara pengetahuan yang mereka miliki dan penerapannya dalam kehidupan mereka sebagai anggota keluarga, masyarakat dan warga negara”. Jadi LKS yang dikembangkan dalam penelitian ini adalah LKS yang menampilkan benda-benda kongkrit yang ada disekitar siswa sehingga siswa dapat menangkap materi pecahan dengan cepat dan tepat (Yulia. 2017)

\section{METODE PENELITIAN}

Jenis penelitian yang digunakan adalah penelitian tindakan (action research). Penelitian tindakan dilakukan untuk meningkatkan kemampuan berpikir kritis dan motivasi belajar Matematika dengan menggunakan power poin dan LKS berbasis kontekstual. Rancangan dalam penelitian ini mengacu pada model spiral atau siklus Tujuan menggunakan model ini adalah apabila pada awal pelaksanaan tindakan ditemukan adanya kekurangan, maka tindakan perbaikan dapat dilakukan pada tindakan selanjutnya sampai pada target yang diinginkan tercapai. Pada masing-masing siklus terdiri dari tahap perencanaan, pelaksanaan tindakan, observasi, dan refleksi (Borg \& Gall, 2003). Jenis data yang digunakan dalam penelitian ini adalah data kualitatif dan kuantitatif yaitu prestasi belajar siswa. Sumber data penelitian ini adalah siswa. Adapun langkah-langkah pengumpulan data adalah diambil dengan cara menggunakan tes akhir tiap siklus setelah melaksanakan pembelajaran untuk melihat kemampuan berpikir kritis siswa dan motivasi belajar.

Instrumen pengumpulan data dalam penelitian ini berupa instrumen Tes berbentuk esay untuk mengukur prestasi siswa sebagai variabel dependen. Tes dilaksnakan pada tiap ahir siklus. Test pada ahir siklus berbentuk soal esay. Sedangkan untuk mengukur motivasi belajar siswa menggunakan angket

Penelitian tindakan (action research) dalam penelitian ini adalah untuk mengetahui peningkatan kemampuan berikir kritis dianalisis dengan mencari ketuntasannya baik secara individu maupun klasikal. ketuntasan individu berdasarkan pada kriteria ketuntasan minimal (KKM) kelas IV SDN Sangari tahun pelajaran 2017/2018 yaitu 70. Adapun ketuntasan klasikal dihitung dengan ketuntasan klasikal sebagai berikut.

$$
\mathrm{KK}=\frac{\mathrm{X}}{\mathrm{Z}} \times 100 \%
$$

Keterangan:

KK : Ketuntasan Klasikal

$\mathrm{X}$ : Jumlah siswa yang memperoleh nilai $\geq$ KKM

\section{Z : Jumlah siswa yang ikut tes}

Data motivasi belajar siswa yang diperoleh dari data angket atau kuesioner (questionnaire) diasajikan dalam bentuk tabel, diagram yang di olah atau dihitung berdasarkan rumus berikut:

$\mathrm{M}_{s p}=\frac{\sum x}{l}$

Keterangan

$\mathrm{M}_{\mathrm{s}}$ :Tingkat motivasi belajar siswa

$x \quad$ :Skor masing - masing pernyataan perorang

$i$ :banyaknya pernyataan 
Rata-rata motivasi belajar siswa keseluruhan

$\mathrm{M}_{\mathrm{s}}=\frac{\sum \pi}{l . n}$

$\mathrm{M}_{\mathrm{s}}$ :Tingkat motivasi belajar

$x \quad$ :Skor keseluruhan pernyataan

$i$ :banyaknya pernyataan

$n$ :banyakny siswa

Persentasi motivasi belajar siswa keseluruhan

Persentasi motivasi belajar siswa dianalisis dengan rumus persentil berikut $\mathrm{M}_{\mathrm{s}}=\frac{\mathrm{Ms}}{4} \times 100 \%$

Tabel 1. Kategori Motivasi

\begin{tabular}{ccc}
\hline Interval (\%) & Nilai & Kategori \\
\hline $86-100$ & $\mathrm{~A}$ & Sangat tinggi \\
\hline $71-85$ & $\mathrm{~B}$ & tinggi \\
\hline $56-70$ & $\mathrm{C}$ & Sedang \\
\hline $41-55$ & $\mathrm{D}$ & Kurang tinggi \\
\hline$\leq 40$ & $\mathrm{E}$ & rendah \\
\hline
\end{tabular}

Setiap prilaku siswa dan guru pada penelitian ini, penilaian keterlaksanaan dengan pilihana ya dan tidak. Analisis menggunakan rumus persentase: $\mathrm{P}=$ (indikator yang terlaksana/ indikator keseluruhan) x 100\%

\section{Hasil Penelitian}

Berdasarkan hasil penelitian dan analisis data diperoleh hasil sebagai berikut:

Tabel. 2. Kemampuan berpikir kritis siswa

\begin{tabular}{clll} 
No & \multicolumn{1}{c}{ ASPEK } & \multicolumn{1}{c}{$\begin{array}{c}\text { HASIL } \\
\text { SIKLUS I }\end{array}$} & \multicolumn{1}{c}{$\begin{array}{c}\text { HASIL } \\
\text { SIKLUS II }\end{array}$} \\
\hline 1 & $\begin{array}{l}\text { Kemampuan } \\
\text { berpikir } \\
\text { kritis }\end{array}$ & $\begin{array}{l}\text { Ketuntasan } \\
\text { klasikal sebesar } \\
61 \%\end{array}$ & $\begin{array}{l}\text { Ketuntasan } \\
\text { klasikal 91\% }\end{array}$ \\
\hline 2 & $\begin{array}{l}\text { Motivasi } \\
\text { belajar }\end{array}$ & $\begin{array}{l}\text { Rata-rata } \\
\text { sedang }\end{array}$ & Rata-rata tinggi \\
\hline 3 & $\begin{array}{l}\text { Aktifitas } \\
\text { guru }\end{array}$ & $\begin{array}{l}\text { Persentase } \\
\text { aktivitas } 76 \%\end{array}$ & $\begin{array}{l}\text { Persentase } \\
\text { aktivitase } \\
100 \%\end{array}$ \\
\hline 4 & $\begin{array}{l}\text { Aktivitas } \\
\text { siswa }\end{array}$ & $\begin{array}{l}\text { Persentase } \\
\text { aktivitas } 82 \%\end{array}$ & $\begin{array}{l}\text { Persentase } \\
\text { aktivitas 100\% }\end{array}$ \\
\hline
\end{tabular}

Dari data hasil tes baik disiklus I diperoleh nilai ketuntasan klasikal sebesar $61 \%$ atau jumlah siswa yang tuntas hanya 14 orand dan yang belum tuntas sebanyak 9 orang. Pada siklus II ketuntasan klasikan naik menjadi $91 \%$ atau jumlah siswa yang tuntas sebanyak 21 orang dan yang belum tuntas sebanyak 4 orang. Dari hasil tes siklus II sudah memenuhi standar yaitu melebihi $85 \%$ siswa yang sudah tuntas secara klasikal. Dari hasil pembagian angket motivasi belajar siswa diperoleh hasil pada siklus I dengan kategori sedang sedangkan pada siklus II motivasi belajar siswa menjadi kategori tinggi. Dari hasil obeservasi aktivitas guru dan siswa pada siklus I masih ada yang belum terlaksana dari keseluruhan aktivitas yang diamati. Pada siklus II dengan adanya perbaikan-perbaikan menjadi $100 \%$ semua aktivitas muncul baik aktivitas siswa maupn aktivitas guru

\section{PEMBAHASAN}

Berdasarkan data hasil penelitian yang dilaksaakan 2 siklus dengan total enam kali pertemuan pada materi pecahan senilai bahwa dengan menggunakan media power poin dan LKS berbasis kontekstual dapat meningkatkan kemampuan berpikir kritis siswa serta meningkatkan motivasi belajar. Hal ini terlihat dari data siklus 1 yang hanya mencapai $61 \%$ ketuntasan secara klasikan untuk aspek kemampuan berpikir kritis dan aspek motivasi belajar hanya rata-rata kategori sedang. Kemudian hasil penelitian di siklus II meningkat secara signifikan menjadi $91 \%$ untuk aspek kemampuan berpikir kritis dan motivasi belajar menjadi kategori tinggi. Hasil penelitian ini sesuai dengan pendapat Daryanto, bahwa Pemanfaatan program aplikasi Microsoft Power Point, memiliki kemampuan yang sangat baik dalam menyajikan sebuah materi dan sudah banyak di gunakan dalam dunia pendidikan. Penggunaan media ini hal yang menarik perhatian siswa (motivasi meningkat) dan dapat meningkatkan pengetahuan siswa dalam hal ini kemampuan berpikir kritis pada materi pecahan (Daryanto. 2013). LKS sebagai sumber belajar dapat digunakan sebagai alternatif media pembelajaran dan termasuk media cetak hasil pengembangan teknologi cetak yang berupa buku dan berisi materi visual (Isnaningsih., 2013). Lembar Kegiatan Siswa (LKS) merupakan suatu bahan ajar cetak berupa lembaran berisi tugas yang di dalamnya berisi petunjuk, langkahlangkah untuk menyelesaikan tugas. LKS dapat berupa panduan untuk latihan pengembangan aspek kognitif maupun panduan untuk pengembangan semua aspek pembelajaran dalam bentuk panduan eksperimen dan demonstrasi 
(Trianto. 2007). Penggunaan media pembelajaran merupakan salah satu cara agar guru untuk mendorong siswa aktif dalam belajar. Motivasi ekstrinsik (dorongan dari luar yaitu dari guru) bukan berarti motivasi yang tidak diperlukan dan tidak baik dalam pendidikan. Bagaimanapun juga seorang siswa yang mendapat motivasi dari luar pasti akan melakukan aktivitas belajar. Dengan demikian, maka siswa tersebut akan mendapat manfaat dari kegiatannya itu terlepas dari faktor yang memotivasi dirinya untuk melakukan aktivitas belajar (Alimuddin, 2009). Berpikir kritis perlu dimiliki oleh peserta didik saat ini. berpikir kritis merupakan salah satu strategi kognitif dalam pemecahan masalah yang lebih kompleks dan menuntut pola yang lebih tinggi. Perkembangan ilmu pengetahuan dan teknologi yang begitu pesat akan menyebabkan informasi yang diterima peserta didik semakin banyak ragamnya, baik sumber maupun muatan informasinya. Oleh karena itu peserta didik dituntut memiliki kemampuan memilih dan memilah informasi yang baik dan benar sehingga dapat memperkaya pemikirannya. Selain itu, peserta didik sebaiknya dibekali dengan kemampuan berpikir yang memadai agar kelak mampu "bertindak" dalam mengembangkan bidang ilmu yang ditekuninya (Surya, 2015)

\section{KESIMPULAN}

Adapun kesimpulan dari penelitian ini yaitu: 1) Penggunaan media power poin dan lembar kerja siswa berbasis kontekstual dapat meningkatkan kemampuan berpikir kritis siswa kelas IV di SD Negeri 2 Tente tahun pelajaran 2018/2019; 2) Penggunaan media power poin dan lembar kerja siswa berbasis kontekstual dapat meningkatkan motivasi belajar siswa kelas IV di SD Negeri 2 Tente tahun pelajaran 2018/2019; 3) Penggunaan media power poin dan lembar kerja siswa berbasis kontekstual dapat meningkatkan aktifitas siswa dan guru kelas IV di SD Negeri 2 Tente tahun pelajaran 2018/2019.

\section{DAFTAR PUSTAKA}

Alimuddin S Miru. 2009. Hubungan Antara Motivasi Belajar Terhadap Prestasi Belajar Mata Diklat Instalasi Listrik Siswa SMK Negeri 3 Makassar. Jurnal Medtek, Volume 1, Nomor 1, April 2009

Borg \& Gall,2003. Education Research. New York : Allyn and Bacon.

Daryanto. 2013. Media Pembelajaran. Yogyakarta: Gava Media.

Isnaningsih., 2013. "Penerapan Lembar Kegiatan Siswa (LKS) Discovery Berorientasi Keterampilan Proses Sains Untuk Meningkatkan Hasil Belajar IPA”, Jurnal Pendidikan IPA Indonesia, Vol. 2, No. 2: 136141.

Johnson, Elaine B. 2014. CTL; Contextual Teaching and Learning. Bandung: MLC

Komalasari, Kokom., 2012. "The Living ValuesBased Contextual Learning to Develop the Students' Character", Journal of Social Sciences, Vol. 8, No. 2: 246-251.

Surya, Muhammad. 2015. Strategi Kognitif Dalam Proses Pembelajaran.

Bandung: Alfabeta.

Trianto. 2007. Model-Model Pembelajaran Inovatif Berorientasi Konstruktifistik.

Prestasi Pustaka. Jakarta.

Yulia Florenty Lamapaha . 2017. Pengembangan Lembar Kerja Siswa Berbasis Kontekstual Berorientasi Penalaran Saintifik. Jurnal Pendidikan Matematika dan Sains, V (1), 2017, 58-68 